\title{
CDT1 wt Allele
}

National Cancer Institute

\section{Source}

National Cancer Institute. CDT1 wt Allele. NCI Thesaurus. Code C52296.

Human CDT 1 wild-type allele is located in the vicinity of $16 q 24.3$ and is approximately 5 $\mathrm{kb}$ in length. This allele, which encodes DNA replication factor Cdt1 protein, plays a role in the modulation of chromosomal duplication. 